\title{
PROPOSALS FOR EMBRYONIC STEM CELL PRODUCTION WITHOUT DESTROYING HUMAN EMBRYOS: SCIENTIFIC AND BIOETHICAL CHALLENGES*
}

\author{
Patricio Ventura-Juncá, Manuel Santos, Juan Larraín**
}

\begin{abstract}
The possibility of using human embryonic stem cells (ESC) for therapeutic purposes raises serious ethical objections, the most fundamental one being that until recently the only way to obtain ESC was with procedures that necessarily destroyed living human embryos. Due to this, research in this field has been rejected by many scientists, bioeticists, and has been banned by law in several countries. Efforts have been made to find procedures to obtain ESC without destroying embyros or putting them at risk. This paper reviews the scientific, technical and ethical aspects of the different strategies developed for this purpose. Embryo biopsy, ESC obtained from "dead" embryos, ESC produced by "parthenogenetic embryos", ESC obtained by Altered Nuclear Transfer and induced pluripotent cells (iPSC) obtained by direct epigenetic reprogramming of somatic cells are the main five alternative reported in recent studies.
\end{abstract}

Key words: ethics, embryonic stem cells, adult stem cells

\section{PROPUESTAS DE PRODUCCIÓN DE CÉLULAS MADRE EMBRIONARIAS SIN DESTRUIR EMBRIONES HUMANOS: RETOS CIENTÍFICOS Y BIOÉTICOS}

Resumen: La posibilidad de usar células madre embrionarias humanas (ESC) para finalidades terapéuticas plantea graves objeciones éticas; la más fundamental es que, hasta hace poco, la única manera de obtener ESC era mediante procedimientos que destruían necesariamente embriones humanos vivos. Debido a esto, la investigación en este campo ha sido rechazada por muchos científicos, bioeticistas y ha sido prohibida por ley en varios países. Se han realizado esfuerzos para encontrar procedimientos que permitan obtener ESC sin destruir embriones o sin ponerlos en riesgo. En este documento examinamos los aspectos científicos, técnicos y éticos de las diferentes estrategias elaboradas para esta finalidad. La biopsia de embriones, ESC obtenidas de embriones "muertos"; ESC producidas por partenogénesis de embriones; ESC obtenidas mediante Transferencia Nuclear Alterada y células pluripotentes inducidas (iPSC), obtenidas mediante la reprogramación epigenética directa de las células somáticas, son las principales cinco opciones informadas en estudios recientes.

Palabras clave: ética, células madre embrionarias, células madre adultas

\section{PROPOSTAS DE PRODUÇÃO DE CÉLULAS-TRONCO EMBRIONÁRIAS SEM DESTRUIR EMBRIÓES HUMANOS: DESAFIOS CIENTÍFICOS E BIOÉTICOS}

Resumo: A possibilidade de se utilizar células-tronco embrionárias humanas (ESC) para finalidades terapêuticas apresenta graves objeções éticas, a mais fundamental é que, até recentemente, era a única maneira de obter ESC mediante procedimentos que destruíam necessariamente embrióes humanos vivos. Devido a isso, a investigação neste campo tem sido recusada por muitos pesquisadores, bioeticistas e proibida por lei em vários paises. Esforços são realizados para encontrar procedimentos que permitam obter ESC sem destruir embrióes ou colocá-los em risco. Neste documento examinamos os aspectos científicos, técnicos e éticos das diferentes estratégias elaboradas para esta finalidade. Biópsia de embrióes, ESC obtidas de embriōes "mortos"; ESC produzidas por partenogênese de embrióes; ESC obtidas mediante Transferência Nuclear Alterada e células pluripotentes induzidas (iPSC), obtidas mediante a reprogramação epigenética direta das células somáticas, são as cinco principais opçóes informadas em estudos recentes.

Palavras-chave: ética, células-tronco embrionárias, células-tronco adultas.

This work was supported by the Concurso de Investigación y Publicaciones 2007-2008. "La UC por el Bien Común. Desafíos y Propuestas para una Sociedad Auténticamente Humana”. Pontificia Universidad Católica de Chile. Vicerrectoría Adjunta de Investigación y Doctorado. Dirección General de Pastoral y Cultura Cristiana.

** Faculties of Biological Sciences and Medicine, Pontificia Universidad Católica de Chile. Chile

Correspondence: venturaj@med.puc.cl 


\section{Introduction}

Embryonic stem cells (ESC) have attracted scientific and public attention, mainly because of two issues. The first one is the promise of regenerative medicine through the replacement of damaged cells with new healthy cells, permitting the treatment and even cure of diseases, many of them without known effective treatments such as Parkinson's disease, diabetes, osteoporosis, spinal cord injuries, Alzheimer's disease, leukaemia and multiple sclerosis(1). The second one is an ethical issue(2). The main ethical objection is that ESC are obtained from human embryos, which implies their destruction. ESC can be obtained from surplus embryos resulting from in vitro fertilization (IVF) or from induced abortions. The production of cloned human embryos is another potential source for obtaining ESC.

Stem cells can also be find in most tissues and organs of a developed animal and human organism and their rôle is to repair or to maintain the tissue in which are they found. They are called adult stem cells (ASC) or somatic stem cells, including those obtained from the umbilical cord. They have some general properties similar to ESC, as well as some differences that will be discussed later.

We will not address the ontological status of the human embryo and its right to life in this paper, although we are aware of the central rôle that this issue has in the debate. However, we can verify that the ethical debate exists and that for many people, governments and legislatures it is not acceptable to use human embryos for this or other purposes, given that it implies risks for the life, integrity and future of the embryos. In fact, this is why some countries have completely banned ESC research or have cut funding for such studies. It is in this context that different efforts have been made to obtain ESC with methods that do not imply risks for human embryos or their destruction. The objective of this paper is to analyse the scientific, technical and ethical aspects of these proposals.

\section{What defines stem cells? Differences between ESC and ASC}

There is no complete scientific consensus on the definition of stem cells, but there is agreement that stems cells have two essential and defining characteristics':

1 http://stemcells.nih.gov/info/basics/basics2.asp II. What are the unique properties of all stem cells?
- They are undifferentiated cells that can be cultured and will proliferate in vitro indefinitely, without differentiating. Thus a population of ESC can divide in a laboratory and give rise to millions of cells. On the contrary, most ASC can divide in vitro for a more limited time. There is ongoing research to explain and overcome this limitation.

- In certain experimental environments ESC can differentiate into different cells of body tissues and thus could be used for transplantation therapy in humans. It was thought that ASC could only differentiate into cells of the tissues in which they exist, but current experimental data, while controversial, shows that ASC can differentiate into several cell types, including cells of the nervous system.

- ESC produce a type of tumour called teratomas. This is a property not yet found in ASC, and is one of the reasons not to begin clinical trials with ESC and research mainly restricted to animals. In contrast, there are many ongoing clinical trials with $\operatorname{ASC}(3)^{2}$. Bone marrow transplantation transplant for the treatment of cancers is a proven therapy(4).

- The ethical limitations in obtaining human ESC have encouraged efforts to obtain them with techniques that would not provoke ethical objections, the most relevant of these is the destruction of human embryos. We will review propositions presented for this purpose, their technical feasibility and the ethical and scientific controversies associated with them.

1. Embryo biopsy. One or more blastomeres are removed from a living embryo, as done in preimplantation genetic diagnosis (PGD)

Technical feasibility. A group of scientists coordinated by Robert Lanza from Advance Cell Technology published the first two papers reporting that ESC had been obtained by this method $(5,6)$. Other researchers have obtained similar results(7).

Research with mouse embryo. Eight-cell stage mouse embryos were biopsied, using a single-cell embryo biopsy technique, similar to the one used in pre-implantation diagnosis of genetic defects(1). Under special culture conditions, cell lines were developed with the morphology and pluripotency marker characteristics of ESC. This was confirmed by the fact that these cell

$2 \mathrm{http}: / /$ clinicaltrials.gov/ct2/results?term=adult+stem+cells 
lines developed the three germ lines, and teratomas, and could produce chimeras when injected in mouse blastocysts. The blastomere-biopsied embryos were implanted and developed to term in a similar proportion compared to control non-biopsied embryos. In a recent study, ESC lines were obtained from two cells, four- and eight-cell mouse embryo that proved to be more efficient ${ }^{1}$.

Research in human embryo. Sixteen unused embryos produced by in vitro fertilization (IVF) were used for the research, with the informed consent of the "owners". Multiple blastomere biopsies were performed from each embryo to reduce the number of embryos needed for the research. Some 91 blastomeres were obtained and cultured in a special medium. They developed 19 outgrowths of embryonic-like stem cells. From these, only two stable human ESC (hESC) cell lines proliferated for more than eight months, showing the morphology and expression of markers of pluripotency and the capacity to form tissues derived from the three embryonic germ layers and to form teratomas. These $\mathrm{hES}$ do not solve the problem of genetic compatibility. They could be stored in banks for use years later in case the biopsied embryo is allowed to continue its development and presents some of the diseases that could be treated with these ESC.

Ethical considerations. This method raises different types of ethical objections:

- The technique implies the use of embryos produced by IVF, which raises ethical objections among many people.

- The fate of the biopsied embryo used for obtaining human ESC. "Surplus" embryos from IVF are generally not implanted; they run the risk of being destroyed, as was the case in this study(8).

- Potential risks for the embryo without benefit. The technique used is similar to that for preimplantation genetic diagnosis (PGD). In most cases, this is done to provide information in deciding about abortion, which is in itself a major ethical problem. The risks for the embryo to remove a blastomere are unknown, and the embryo receives no benefit with the procedure. For these reasons, the authors of the cited article do not recommend the procedure to be applied, except for PGD. There are also questions about the possibility of doing the PGD and the derivation of human ESC from only one blastomere. If two blastomeres are removed, the risk for the viability of the embryo increases(9).

- Risk of reprogramming a new embryo? Under the conditions of this technique there is no theoretical or empirical evidence that this can happen.

At this stage of knowledge, probably few parents would accept the risks of an embryo biopsy just to obtain ESC that could potentially benefit their child. And in the context of PGD there are still unsolved technical aspects. Embryo biopsy could reduce the probability of a successful IVF. With this method the number of ESC is very low, which could alter the accuracy of PGD. The results for the parents could finally be very few or no stem cell line and poorer cells for $\operatorname{PGD}(10)$.

\section{ESC Obtained from "dead" embryos.}

Criteria for embryonic death: Technical feasibility. This alternative's hypothesis seeks to apply similar criteria to the embryo as that of brain death used when transplanting organs from dead people.

- In 2004 Landry and Zucker proposed a definition for embryo death applying the criteria of organismic death used in relation to brain death as the "irreversible loss of the capacity for all ongoing and integrated organic functioning" (11). They argued that embryo death is the loss of capacity of a 4 - to 8-cell human embryo for ongoing and integrated cellular division, growth and differentiation. They further argued that even if individual cells remain alive with the irreversible loss of these capacities the embryo could be properly considered organismically dead. How can this be objectively determined? The authors propose that death is equivalent to the "irreversible arrest of cleavage". But they recognize the need for objective criteria to determine irreversible arrest. In 2006, they continued in their research to establish embryo death (12). In a retrospective study with 444 embryos, produced by IVF, that were considered nonviable, they found that 142 at day 5 had hypocellularity and lack of compaction. None of them progressed to compacted morula or normal blastocyst. The authors propose this criteria for assigning irreversible arrested development and hence "irreversible loss of integrated organic function".

- Zhang et al (2006) developed embryonic stem cells from arrested embryos(13). 161 "surplus" 
embryo produced by IVF were donated for the research. When no cleavage division of blastomeres was observed for 24 to 48 hours in the in vitro culture (IVC), the authors considered that an embryo was in a stage of irreversible arrest. Using this criterion with the 161 embryos, the results were the following:

- 29 developed normally until cells were extracted from IMC of the blastocyst.

- 119 arrested 3 to 5 days after fertilization: early arrested embryos

- 13 arrested 6 to 7 days after IVF: late arrested embryos

- The authors tried to derive ESC from each of these 3 groups:

- ESC lines were derived from eight of the 29 normally developing embryos.

- No ESC lines were derived from the early arrested embryos (3-5-days)

- One ESC line was obtained from one of 13 late arrested embryos (6-7 days) that seem to have the properties of normal ESC.

- The authors do not state explicitly that arrested embryos are dead. They only point out that, as they are not viable, their use for obtaining ESC would produce fewer ethical objections.

Scientific and technical considerations. The central question about this approach is how to diagnosis an embryo as dead. The embryo must have at least part of the cells of its Internal Mass Cell (IMC) alive in an appropriate condition for deriving ESC. Brain death has very defined criteria, which cannot be applied to the embryo. Consequently, the analogy cannot be made. How can the loss of integration functions in the embryo be determined? There are at least two questions to resolve that have been pointed out by several scientists(14):

- $\quad$ Irreversible arrest is undoubtedly necessary for determining that an embryo is dead, but: Is it sufficient? Is it equivalent to "irreversible loss of integrated organic function," as stated by Landry and Zucker? The technique will continue to be compromised by the uncertainty as to what constitute embryonic death. There are clear criteria for defining someone as irreversibly brain dead but no such clarity exists in the case of embryonic death. As Pearson notes the procedure is rendered unacceptable if there is even a remote possibility of reviving an embryo(14).
- $\quad$ Second, even if the definition would be accepted, the question remains: are there reliable methods for determining when an embryo has arrived to a state of irreversible arrest? Landry and Zucker conclude from their retrospective study that the lack of compaction and hypocellularity are sufficient criteria for defining irreversible arrest because none of the embryos with these characteristics progressed to compacted morula or normal blastocyst. But this is an insufficient argument to affirm that the embryo is dead. The only logical conclusion is that these embryos are not viable. In a topic like this, retrospective studies have great limitations and prospective studies are limited by ethical considerations.

The fact that the source is unused embryos from fertility treatments may encourage IVF embryo production.

Scientific and ethical questions and objections: The quality of the ESC lines obtained from what are considered dead embryos is a matter of concern. In this respect, George Daley of the Harvard Stem Cell Institute wonders if cells from arrested embryos are not problematic, given that something provoked the arrest of embryo ${ }^{3}$.

From dead embryos to discarded embryos. The lack of a clear criteria for when to consider an embryo as dead has led to a redirecting of efforts to obtain ESC lines from embryos of poor quality that have attained the blastocyst stage. Lerou et al.(15) found that early arrested embryos (3 days) are very inefficient for obtaining ESC lines, $0.6 \%$ (1/171), those arrested at day $54.1 \%(10 / 242)$ and those that reach the blastocyst stage, $8.5 \%$ (8/94). Based on these results, they verify that poor-quality embryos rejected for clinical use on day 5 post-fertilization have an efficiency for hESC drivation comparable to that of frozen embryos. They add that there are potentially hundreds of thousands of embryos available for hESC derivation, given the enormous number of embryos discarded in the United States in assisted reproductive technology because the embryos are of low morphological grade and have a low developmental

3 Quoted by Antony Barnett and Robin McKie. The Observer, Sunday, September 242006. 
potential. This is an expression of the slippery slope that begins with an imprecise definition of a dead embryo, continues with the use of embryos considered as not being viable, and finally of embryos of poor quality. It is clear that not all the poor quality embryos that are discarded are dead.

\section{ESC produced by "parthenogenetic embryos"}

- What is parthenogenesis? Parthenogenesis is the development of an embryo directly from an oocyte without fertilization. Many animals (such as fish, ants, flies, honey bees, amphibians, lizards and snakes) and plant species reproduce via parthenogenesis. Mammals are not capable of this type of reproduction. Mammalian embryonic development requires gene expression from the paternal genome. Parthenogenetic mouse embryos develop only to the early limb bud stage (16).

- Scientific and technical aspects.

- Development of mammalian parthenote to blastocyst stage. For a decade there have been efficient methods for producing parthenotes. The first method described in the literature consists of arresting oocytes at the second meiotic metaphase (MII) and chemically activating them with cytochalasin, a drug that prevents extrusion of the second polar body(17). Diploid is maintained and the resulting pseudo zygote can develop into a blastocyst from which ESC can be isolated. Another method includes preventing the extrusion of the first polar body. A tetraploid oocyte is formed that is transformed into a diploid with the extrusion of the second polar body(18). The two methods produce parthenote that result in a different type of genetic parthenotes. Different methods to develop parthenotes in mammals, including humans, have been developed in recent years (19). Even more recently, methods have been developed to produce parthenogenetic human blastocysts(20).

- Development of ESC from parthenogenetic blastocyst in animals. The first ESC lines from parthenotes were developed from mice in 1983 (21). Subsequently, parthenogenetic ESC (pESC) lines have been developed from non- human primates $(22,23)$, rabbits $(24,25)$ and mice $(16,26)$. There is evidence that ESC are produced more efficiently from parthenogenetic embryos than from cloned embryos(27).

- Development of ESC from human parthenogenetic blastocysts. Revazova et al reported the first $\mathrm{pESC}$ lines derived from human parthenotes $(28,29)$. Their behaviour is similar to regular ESC in morphology and can give rise to the derivatives of the three germ layers in immune deficient mice. They have proliferated for more than 10 months. These pESC would be compatible with the donor's immune system. Other reports have also been recently published $(30,31)$. It is interesting that the work reported by Hwang, that was once touted as the first to create human ESC lines through somatic cell nuclear transfer, has now been discovered to have originated by parthenogenesis(32).

- Scientific and ethical questions. Two major questions arise:

- Is a parthenote blastocyst an altered human embryo or just a ball of cells without organization? This is a major anthropological question with significant ethical consequences. How to resolve this doubt seems difficult. Up to the development of blastocyst, does this entity have the characteristics of an organism? It seems to have an integrated and organized functioning (selforganization) and capacity for development and certain intrinsic autonomy (self-development) from the environment (33). Could it progress to other stages of development if implanted? In fact, parthenogenetic embryos have been implanted in different species and have reached a certain degree of development, although always abnormal $(34,35)$. Are these abnormal embryos, or just a group of disorganized tissue? In this respect Kevin Fitzgerald argues that in mammals you cannot obtain parthenogenetic offspring. If a spontaneous parthenogenetic growth could occur it would not be an embryo. But if parthenogenetic embryos are artificially induced, there is a valid question about what is being produced $^{4}$. The discussion continues and at the center is the question of the ontological status

4 Barry P. Science News Online Week of Oct. 20, 2007; Vol. 172, No. 16. 
of parthenotes, which needs to be established before activated oocytes can be considered as an ethical source for pluripotent stem cells (36).

- Another ethical concern is how to obtain healthy eggs. In one study, as pointed out by one of the authors, J Janus, the oocytes were obtained from Russian women undergoing IVF procedures. No payments were made to the donors, but Janus states that the researchers did cover some costs of the IVF treatment"(37).

- There is also the question of whether these pESC lines will be useful for regenerative medicine. What are the effects of not having parental imprinting? Brevini and Gandolfi (31) raise the question of the genetic stability and safety of such cells given that aneuploidy in human oocytes is relatively high. Concerns are expressed by other experts. Jeanne F. Loring $^{4}$ has pointed out negative consequence can arise if the cell line is homozygous. She notes that in heterozygous cells the influence of either the paternal or maternal genes in determining whether a cell becomes cancerous is offset by the influence of the genes of the other parent. She is concerned that a gene copying error could result in a cell with two identical copies of the same gene, thus altering the balance of parental genes. This could in turn result in the cell becoming a malignant growth. This question needs more scientific research to be answered.

\section{Altered Nuclear Transfer (ANT) and Oocyte Assisted Reprogramming (OAR).}

- What is ANT-OAR? William Hurlbut, a member of the US President's Council on Bioethics (PCBE), was the author of this proposal on December 2004. ANT consists of a modification of the technique of nuclear transfer with a preemptive genetic and epigenetic modification of the nucleus of the somatic cell to be transferred(38). When there is also an alteration of the oocyte cytoplasm before transfer is done, the technique is termed ANT with OAR. We will first focus our analysis on ANT alone. The hypothesis of those who defend this line of research is that the technique will result in a biological entity without the characteristics of an organism. W. Hurlbut argues that these alterations prevent the potential for coordinated organization and developmental, which defines the embryonic organism. Thus, his method would allow for the generation of ESC lines using a biological entity that would not be considered an embryo(39). This is an hypothesis that must be empirically proved and philosophically analyzed.

- ANT: Scientific technical and ethical aspects. ANT was the initial proposition. The proponents of this technique argue that the $\mathrm{Cdx} 2$ gene is indispensable for the constitution of an embryo. This gene would be essential for the integration of the new organism as a whole. If the gene is silenced there is no organism, but rather only a biological entity lacking of self-organization and development. From an empirical point of view there are 2 main objections to this statement. The research that concluded that the $\mathrm{Cdx} 2$ gene was expressed very early in embryonic development (40) and that it was present in the first cleavage in only one of the blastomeres was retracted (41). Other studies have demonstrated that the $\mathrm{Cdx} 2$ gene is not expressed at the two stage blastomeres in mice(42). Thus, this gene might not be essential for the first stages of development.

There is one published paper in which ESC lines were obtained with this strategy in mice. The technique consisted of silencing the $\mathrm{Cdx} 2$ gene from the nucleus of the somatic cell transferred to the oocyte(43). The cloned blastocysts were morphologically abnormal with no expression of the CDx2 gene. They lacked a functional trophoblast and failed to implant in foster mothers. Nonetheless, ESC lines were derived from these blastocysts. To test their pluripotency they were injected into diploid blastocysts. Postnatal chimeras were generated. The injected $\mathrm{Cdx} 2$ deficient ESC lines contributed to the formation of most tissues in the chimeras, with the exception of the intestine, where all the cells were $\mathrm{Cdx} 2$ positive derived from the host blastocyst. It is known that the $\mathrm{Cdx} 2$ gene is necessary for the development of the gastro intestinal tract(44).

It is relevant that Meissner and Jaenisch, authors of this article(43), recognize that the ethical dilemma may not be resolved since the $\mathrm{Cdx} 2$-deficient embryo appears to be normal in the first stages of development before the $\mathrm{Cdx} 2$ gene is expressed.

Another aspect is that the function of the $\mathrm{Cdx} 2$ gene could be restored in the ESC derived by this 
technique. In theory, the so-called biological entity by its defenders could be transformed into an embryo during the development to blastocyst by restoring the capability of the $\mathrm{Cdx} 2$ at the stage of 2 or 4 cells. After recuperating the status of being an embryo, it could be possible to transform again the embryo into a biological entity by silencing the $\mathrm{Cdx} 2$ gene. It seems unlikely that the ontological condition of a biological organism could depend only on the simple silencing and activating of a gene. Thus, we could have new human beings that appear and disappears with this action alone. This demonstrates that the ethical aspects have not been solved and that the facts show that what are being produced are disabled embryos and not biological entities.

The philosophical debate has centered on what are sufficient and necessary characteristics of a new organism? ${ }^{5}$. How can we differentiate a biological entity from an organism? Scientists and philosophers with the same anthropology regarding the human embryo differ in their evaluation of this technique (45-47). Although an in-depth discussion of the different positions is beyond the objectives of this article, we agree with the view stated above that the silencing of the $\mathrm{Cdx}$ gene does not clearly produce something that is not an embryo.

- ANT with OAR. Scientific, technical and ethical aspects. A group of thirty-five scientists, moral philosophers and theologians sign a joint statement supporting this alternative(48). The hypothesis of the ANT modification is that a combination of epigenetic alterations of both the somatic nucleus and the enucleated egg would directly produce a pluripotent cell "that from the beginning would be clearly and unambiguously distinct from, and incompatible with, those of an embryo"(48). W Hurlbut, the father of the proposal, argues that ANT-OAR results in a cell that at no point has the potential for integrated organization and coordinated development and behaves directly like pluripotent cell ${ }^{6}$.

The ethical debate has been similar to that around ANT alone. In our opinion, much of the ethical discussion remains theoretical given that there is

5 Communio 2004 and $2005 \mathrm{~N}^{\circ} 31$ and 32 . Critiques of Altered Nuclear Transfer (ANT) and Oocyte Assisted reprogramming (OAR)

6 Hurlbut W. 2007 http://www.alterednucleartransfer.com/publications/1.pdf no empirical data that this technique (ANT-OAR) is feasible. There is a debate as to whether this is a sound scientific hypothesis (49). We think that until animal research arrives to some concrete results, it is difficult to make scientific and ethical conclusion.

\section{Direct epigenetic reprogramming of somatic cells to induce pluripotent cells (iPSC)}

- Development of epigenetic reprogramming of somatic cells. The capacity of the oocyte to dedifferentiate somatic cells in the process of cloning resetting them to their embryonic epigenetic state was a major discovery in biology that is still not well understood(50). Somatic cells can also be reprogrammed to a pluripotency state by fusion with $\operatorname{ESC}(51,52)$. These facts led to the hypothesis that certain factors present in the ESC could induce epigenetic reprogramming of somatic cells to produce embryonic stem cells without using an egg.

In 2006 Takahashi and Yamanaka published a seminal paper on nuclear reprogramming research demonstrating that this was possible (53). They hypothesized that factors that play a crucial role in maintaining pluripotency in ESC could also induce pluripotency if introduced to somatic cells. They first selected 24 genes as candidates for this purpose. These genes are expressed in ESC and are responsible for their unique characteristics. The genes were introduced by retroviral transduction into mice skin cells (fibroblasts). The fibroblasts had been previously modified by the introduction of a Neomycin resistant gene in the Fbx15 gene by homologous recombination. The Fbx15 gene, although it is not essential for maintaining pluripotency, is activated in ESC. Thus, cell colonies in which the Fbx15 gene activated will not be destroyed in the presence of Neomycin, and this serves in selecting colonies that resemble ESC. In their first experiments with the introduction of the 24 genes, Takahashi and Yamanaka obtained a small percentage of drug-resistant colonies. These cells were similar to ESC in morphology, growth and markers of pluripotency. Nanog was demethylated but not Oct4. No drug resistant colonies were obtained when only one gene was introduced. 
Through several sequential experiments to determine which genes were essential for this reprogramming process, Takahashi and Yamanaka identified 4 genes which, when injected into skin fibroblasts, were more efficient in producing what they called induced pluripotent stem cells (iPSC). These cells demonstrated some of the typical characteristics of ESC: pluripotency markers, capacity to form teratomas and to produce fetal chimeras when injected in a mouse blastocyst. The researchers were surprised that the NANOG gene, known for its importance in maintaining pluripotency, was not one of the essential genes to produce iPSC. With the reprogramming process through the transduction of the four genes, the NANOG gene and some other endogenous genes involved in the pluripotent state of the cells were expressed, but not the endogenous Oct 4 gene. This demonstrates that the introduction of the genes produces a vast modification of the transcription state of the cells. Although the cells had similar characteristics to ESC they were different in some aspects: There was some dissimilarity in gene expression and none of the fetal chimeras produced with these cells developed into an adult mouse. The epigenetic reprogramming was done first with mouse embryonic fibroblasts and then with adult mouse fibroblasts obtained from the tail-tip.

\section{- Confirmation and advances in the epigenetic reprogramming of somatic cells to iPSC}

Since the publication of Takahashi and Yamanaka an impressive amount of research has been done up to the present. In June-July 2007, three papers were published reporting the production of iPSC by epigenetic reprogramming(54-56). These investigations made some modifications in the technique, especially in the selection strategy. They not only confirmed the discovery made by Takahashi and Yamanaka, but also resolved some of the problems pointed out by them, such as the activation of the Oct 4 endogenous gene, the generation of viable chimeras and the confirmation that the maintenance of the pluripotent state of the cells was mainly due to the activation of endogenous pluripotency genes such as Oct4, Sox 2 and Nanog.

Soon afterwards, Meissner et al. (57) managed to select the iPSC by morphology without genetically modifying the fibroblasts, as was done in previous experiments. The use of genetically unmodified fibroblast donors eliminates a possibly harmful factor for the future use of iPSC in humans. To monitor the reprogramming process, they introduced an enhanced green fluorescent protein (GFP) marker in the Oct 4 locus.

An important step forward was the production of iPSC without introducing the oncogene c-Myc $(58,59)$. It has been reported that the c-Myc gene can be reactivated in animal chimeras derived from iPSC.

The epigenetic process has also been successful with other somatic cells in mouse. Induced pluripotent stem cells have been generated from adult liver cells $(60)$, from mature B lymphocytes(61), and from pancreatic $\beta$ eta(62). In some cases, efficiency was lower(59) and in others there was less tumor formation(58).

Differentiation of iPSC into different types of cells had been proven in vivo (generation of teratomas and chimeras) but not in vitro. In vitro differentiation of mouse iPSC into cells of the cardiovascular and haematopoietic lineages were then achieved (63). These results are promising advances in developing compatible haematopoietic and cardiovascular regenerative therapies in humans.

\section{- Potential of iPSC for treating diseases in animals.}

The therapeutic potential of iPSC has been tested for the first time in two recent studies. The first paper reports the correction of a mouse model with humanized sickle cell anaemia, treated with transplantation of haematopoietic progenitors obtained in vitro from autologous iPSC(64).

A second investigation managed to obtain functional neural cells from mouse iPSC (65). After producing a model of Parkinson's disease in a group of rats, one group was treated with the neural cells derived from iPSC and another group served as control. An improvement in the symptoms of the treated rats was observed in comparison to the control group.

\section{- Production of iPSC from human somatic cells.}

Takahashi, Yamanaka (2007) and their team reproduced their original work in reprogramming mouse fibroblast with the reprogramming of human skin, synovial and newborn fibroblasts(66). They used the same four factors, Oct4, Sox2, Klf4 and c-Myc, introduced 
to the fibroblast by retroviral infection. The authors concluded that their study opened the way to generate pluripotent stem cells that are specific to patients and diseases eliminating the risk of rejection. They argued that despite retroviral integration, human iPSC could contribute to understanding disease mechanisms and have applications in drug screening and toxicology. A second article published simultaneously achieved similar results, although in this case researchers used a different combination of transcription factors: Oct4, Sox2, Nanog and Lin28(67). Two other studies from different researchers have also obtained iESC from human somatic cells with similar results as the previous first studies $(68,69)$.

Differentiation of human iPSC is an essential step for their use in therapies. Dimos et al. reported the generation of human iPSC from fibroblasts of a patient with amyotrophic lateral sclerosis (ALS). Using a similar protocol for the differentiation of ESC, they successfully managed to differentiate in vitro the iPSC into motor neurons of the type destroyed in ALS(70).

Park et al have derived human iPSC from a wide range of genetic diseases(71). This is an important advance for the in vitro study of normal and pathologic development, allowing for a better understanding of the diseases and possible treatments.

\section{- Scientific and ethical considerations}

The impressive advances obtained in the reprogramming of somatic cells to a pluripotent state that seems to be identical to ESC may imply a major scientific breakthrough and the achievement of ethical consensus regarding the research and the future of regenerative medicine for complex and currently incurable diseases. However, there are still many scientific and technical aspects to overcome before it is ethically acceptable to begin clinical trials

Researchers are aware that there are some major difficulties to surmount before using reprogrammed cells for therapeutic applications in human beings. Some impediments have been surmounted: the c-myc, a known oncogene used in the first experiments has proven to be dispensable for direct reprogramming of somatic cells $(56,57)$, and the use of transgenic donors (modified fibroblasts) is not crucial for the selection of the iPSC colonies(55). But there are still major concerns
- The first is the potentially harmful effects involved in the use of retroviral vector for introducing ectopic genes. Researchers are seeking alternatives that could accomplish the reprogramming of somatic cells while circumventing the introduction of genes. This is probably the most important challenge that investigators are trying to overcome.

- The second is the low efficiency of the method.

- Thirdly, there is the production of teratomas. iPSC, as ESC, can produce teratomas when implanted under the skin. Before advancing to therapeutic applications, it will be necessary to clearly demonstrate that differentiated iPSC cells do not produce tumors in hosts. Despite the production of iPSC without c-myc gene, the entire problem has not been resolved.

- Finally there is the challenge to progress in the generation of human iPSC and the need to develop consistent differentiation procedures to allow its use in regenerative medicine.

From an ethical perspective, the reprogramming of somatic cells to obtain iPSC bypasses the major problems involved in obtaining and using ESC. There is no destruction or manipulation of the embryo, nor the need for oocytes. Its potential in the treatment of a host of diseases in different areas of medicine offers the possibility of consensus for the first time between scientists and ethicists with different anthropological and ethical views. The cloning of human embryos for obtaining ESC compatible with patients for treating diseases, independent of the ethical problems involved, has less of a future than epigenetic reprogramming. It is relevant that Ian Wilmut on Novembrer 2007 decided to abandon his research into human cloning and switched to research in the line of reprogramming somatic cells to iPSC. His decision was not motivated primarily by ethical considerations so much as for practical and scientific reasons $(72)^{7}$. Other scientists think that with the advances in this technique, the so-called human therapeutic cloning will most likely be left behind (73).

For all those who recognize a human being in the human embryo, with the dignity and rights of a member of the human family, this is a major line of research that merits significant support and work. But one should be cautious in creating too much expectation of a prompt

$7 \quad$ Telegraph Interview to Ian Wilmut, Novembrer 2007. 
application in regenerative medicine in humans. The technical and scientific problems pointed out above must be overcome.

\section{Conclusions}

The different approaches described in this paper to obtain pluripotent cells without destroying or using human embryos have been discussed from a scientific and ethical viewpoint. We think that the advances in obtaining human iPSC by direct epigenetic reprogramming is the most promising strategy for obtaining pluripotent cells without using embryos or eggs, and thus represent the closest convergence of science and ethics.

\section{References}

1. Scolding N. New cells from old. The Lancet 2001; 357(9253): 329-330.

2. Faggioni MP. Anthropological and ethical reflections on the production and use of embryonic stem cells. Cell Prolif 2008; 41 Suppl 1:71-77.

3. Levicar N, Pai M, Habib NA, et al. Long-term clinical results of autologous infusion of mobilized adult bone marrow derived CD34+ cells in patients with chronic liver disease. Cell Prolif 2008; 41 Suppl 1:115-125.

4. Ballen KK, King RJ, Chitphakdithai P, et al. The national marrow donor program 20 years of unrelated donor hematopoietic cell transplantation. Biol Blood Marrow Transplant 2008; 14 (9 Suppl): 2-7.

5. Chung Y, Klimanskaya I, Becker $S$, et al. Embryonic and extra embryonic stem cell lines derived from single mouse blastomeres. Nature 2006; 439: 216-219.

6. Klimanskaya I, Chung Y, Becker S, Lu SJ, Lanza R. Human embryonic stem cell lines derived from single blastomeres. Nature 2006; 444(7118): 481-485.

7. Wakayama S, Hikichi T, Suetsugu R, et al. Efficient establishment of mouse embryonic stem cell lines from single blastomeres and polar bodies. Stem Cells 2007; 25(4): 986-993.

8. Abbott A. 'Ethical' stem-cell paper under attack. Nature 2006; 443(7107): 12.

9. Simpson JL. Medicine: blastomeres and stem cells. Nature 2006; 444(7118): 432-435.

10. Hudson KL. Embryo biopsy for stem cells: trading old problems for new. The Hastings Center Report 2006; 36(5): 5051.

11. Landry DW, Zucker HA. Embryonic death and the creation of human embryonic stem cells. J Clin Invest 2004; 114: 1184-1186.

12. Landry DW, Zucker HA, Sauer MV, Reznick M and Wiebe L. Hypocellularity and absence of compaction as criteria for embryonic death. Regenerative Medicine 2006; 1(3): 367-371.

13. Zhang X, Stojkovic P, Przyborski S, et al. Derivation of human embryonic stem cells from developing and arrested embryos. Stem Cells 2006; 24(12): 2669-2676.

14. Pearson H, Abbott A. Stem cells derived from 'dead' human embryo. Nature 2006; 443(7110): 376-377.

15. Lerou PH, Yabuuchi A, Huo H, Takeuchi A, Shea J, Cimini T, Ince TA, Ginsburg E, Racowsky C, Daley GQ. Human embryonic stem cell derivation from poor-quality embryos. Nat Biotechnol 2008; 26(2): 212-214.

16. Kim K, Lerou P, Yabuuchi, A et al. Histocompatible Embryonic Stem Cells by Parthenogenesis. Science 2007; 315(5811): 482-486.

17. Balakier H, Tarkowski AK. Diploid parthenogenetic mouse embryos produced by heat-shock and Cytochalasin. $B J$. Embryol. Exp. Morphol 1976; 35: 25-39.

18. Kubiak J, Paldi A, Weber M, Maro B. Genetically identical parthenogenetic mouse embryos produced by inhibition of the first meiotic cleavage with cytochalasin D. Development 1991; 111: 763-769.

19. Cibelli JB, Cunniff K, Vrana KE. Embryonic Stem Cells from Parthenotes. Methods in Enzymology 2006; 418: 117135.

20. Brevini TAI, Gandolf F. Parthenotes as a source of embryonic stem cells. Cell Prolif 2008; 41(1): 20-30.

21. Kaufman MH, Robertson EJ, Handyside AH, Evans MJ. Establishment of pluripotential cell lines from haploid mouse embryos. J Embryol Exp Morphol 1983; 73: 249-261.

22. Cibelli JB, Grant KA, Chapman KB, et al. Parthenogenetic stem cells in nonhuman primates. Science 2002; 295: 819. 
Proposals for embryonic stem cell production without destroying human embryos - Patricio Ventura-Juncá, Manuel Santos, Juan Larrain

23. Dighe V, Clepper L, Pedersen D, et al. Heterozygous embryonic stem cell lines derived from nonhuman primate parthenotes. Stem Cells 2008; 26(3): 756-766.

24. Fang ZF, Gai H, Huang YZ, Li SG, et al. Rabbit embryonic stem cell lines derived from fertilized, parthenogenetic or somatic cell nuclear transfer embryos. Exp Cell Res 2006; 312: 3669-3682.

25. Wang S, Tang X, Niu Y, Chen H, et al. Generation and characterization of rabbit embryonic stem cells. Stem Cells 2006; 25: 481-489

26. Lee ST, Choi MH, Lee EJ, et al. Establishment of autologous embryonic stem cells derived from preantral follicle culture and oocyte parthenogenesis. Fertil Steril 2007; 88(4S): 1193-1203.

27. Ju JY, Park YC, Gupta MK, Uhm SJ, et al. Establishment of stem cell lines from nuclear transferred and parhenogenetically activated mouse oocytes for therapeutic cloning. Fertil Steril 2008; 89(5 Suppl): 1314-1323.

28. Revazova ES, Turovets NA, Kochetkova OD, et al. Patient-specific stem cell lines derived from human parthenogenetic blastocysts. Cloning Stem Cells 2007; 9(3): 432-449.

29. Revazova ES, Turovets NA, Kochetkova OD, et al. HLA Homozygous Stem Cell Lines Derived from Human Parthenogenetic Blastocysts. Cloning Stem Cells 2008; 10(1): 11-24.

30. Mai Q, Yu Y, Li T, Wang L, et al. Derivation of human embryonic stem cell lines from parthenogenetic blastocysts. Cell Res 2007; 17(12): 1008-1019.

31. Brevini TA, Gandolf F. Parthenotes as a source of embryonic stem cells. Cell Prolif 2008; 41(Suppl 1): 20-30.

32. Vogel G. Origin of Hwang's Stem Cell Line Explained. Science NOW, Daily News, 2 August 2007.

33. Watt H. Embryos and pseudoembryos: parthenotes, reprogrammed oocytes and headless clones. J Med Ethics 2007; 33(9): 554-556.

34. Marshall VS, Wilton LJ, Moore HD. Parthenogenetic activation of marmoset (Callithrix jacchus) oocytes and the development of marmoset parthenogenones in vitro and in vivo. Biol Reprod 1998; 59(6): 1491-1497.

35. Kure-bayashi S, Miyake M, Okada K, et al. Successful implantation of in vitro-matured, electro-activated oocytes in the pig. Theriogenology 2000; 53(5): 1105-1119.

36. Rao M, Maureen, Condic LM. Alternative Sources of Pluripotent Stem Cells: Scientific Solutions to an Ethical Dilemma. Stem Cells and Development 2008; 17(1): 1-10.

37. Cyranoski D. Activated eggs offer route to stem cells. Nature 2007; 448(7150): 116.

38. The President's Council on Bioethics. Alternative sources of human pluripotent stem cells. A White Paper. Washington, DC: The President's Council on Bioethics: 2005.

39. Hurlbut WB. Altered nuclear transfer as a morally acceptable means for the procurement of human embryonic stem cells. Perspect Biol Med 2005; 48(2): 211-228.

40. Deb K, Sivaguru M, Yong HY, Roberts RM. Cdx2 gene expression and trophectoderm lineage specification in mouse embryos. Science 2006; 311: 992.

41. Roberts RM, Sivaguru M, Yong HY. Retraction. Science 2007; 317(5837): 450.

42. Torres-Padilla ME, Parfitt DE, Kouzarides T, Zernicka-Goetz M. Histone arginine methylation regulates pluripotency in the early mouse embryo. Nature 2007; 445(7124): 214-218.

43. Meissner A, Jaenisch R. Generation of nuclear transfer-derived pluripotent ES cells from cloned Cdx2-deficient blastocysts. Nature 2006; 439(7073): 212-215.

44. Chawengsaksophak K, James R, Hammond VE, et al. Homeosis and intestinal tumours in Cdx2 mutant mice. Homeosis and intestinal tumours in Cdx2 mutant mice. Nature 1997; 386(6620): 84-87.

45. Colombo R. Altered Nuclear Transfer as an Alternative Way to Human Embryonic Stem Cells: Biological and Moral Notes. Communio 2004; 31: 645-648.

46. Austriaco NPG. The Moral Case for ANT-Derived Pluripotent Stem Cell Lines. National Catholic Bioethics Quarterly 2006; 6(3): 517-537.

47. Hurlbut WB, George RP, Grompe M. Seeking consensus: a clarification and defense of altered nuclear transfer. The Hastings Center Report 2006; 36(5): 42-50.

48. Arkes H, Austriaco NP, Berg T, et al. Production of Pluripotent Stem Cells by Oocyte Assisted Reprogramming Joint Statement. National Catholic Bioethics Quarterly 2005; 5(3): 579-583.

49. Byrnes WM. The flawed scientific basis of the altered nuclear transfer-oocyte assisted reprogramming (ANT-OAR) proposal. Stem Cell Rev 2007; 3(1): 60-65. 
50. Wilmut I, Schnieke AE, McWhir J. et al. Viable offspring derived from fetal and adult mammalian cells. Nature 1997; 385: 810-813.

51. Cowan CA, Atienza J, Melton DA, Eggan K. Nuclear reprogramming of somatic cells after fusion with human embryonic stem cells. Science 2005; 309, 1369-1373.

52. Yu J, Vodyanik MA, He P, Slukvin II, Thomson JA. Human embryonic stem cells reprogram myeloid precursors following cell-cell fusion. Stem Cells 2006; 24(1): 168-176.

53. Takahashi K, Yamanaka S. Induction of pluripotent stem cells from mouse embryonic and adult fibroblast cultures by defined factors. Cell 2006; 126: 663-676.

54. Okita K, Ichisaka T, Yamanaka S. Generation of germline-competent induced pluripotent stem cells. Nature 2007; 448(7151): 313-317.

55. Wernig M, Meissner A, Foreman R, et al. In vitro reprogramming of fibroblasts into a pluripotent ES-cell-like state. Nature 2007; 448(7151): 318-324.

56. Maherali N, Sridharan R, Xie W, et al. Directly reprogrammed fibroblasts show global epigenetic remodeling widespread tissue contribution. Cell Stem Cell 2007; 1(1): 55-70.

57. Meissner A, Wernig M, Jaenisch R. Direct reprogramming of genetically unmodified fibroblasts into pluripotent stem cells. Nature Biotechnology 2007; 25: 1177-1181

58. Nakagawa M, Koyanagi M, Tanabe K, et al. Generation of induced pluripotent stem cells without Myc from mouse and human fibroblasts. Nature Biotechnology 2008; 26(1): 101-106.

59. Wernig M, Meissner A, Cassady JP, Jaenisch R. c-Myc is dispensable for direct reprogramming of mouse fibroblasts. Cell Stem Cell 2008; 2: 11-12.

60. Aoi T, Yae K, Nakagawa M, et al. Generation o Pluripotent Stem Cells from Adult Mouse Liver and Stomach Cells. Science. 2008; 321(5889): 699-702.

61. Hanna J, Markoulaki S, Schorderet P, et al. Direct reprogramming of terminally differentiated mature B lymphocytes to pluripotency. Cell 2008; 133(2): 250-264

62. Stadtfeld M, Brennand K, Hochedlinger K. Reprogramming of pancreatic beta cells into induced pluripotent stem cells. Curr Biol 2008; 18(12): 890-894.

63. Schenke-Layland K, Rhodes KE, Angelis E, et al. Reprogrammed mouse fibroblasts differentiate into cells of the cardiovascular and hematopoietic lineages. Stem Cells 2008; 26(6): 1537-1546..

64. Hanna J, Wernig M, Markoulaki S, et al. Treatment of sickle cell anemia mouse model with iPS cells generated from autologous skin. Science 2007; 318(5858): 1920-1923.

65. Wernig M, Zhao JP, Pruszak J, et al. Neurons derived from reprogrammed fibroblasts functionally integrate into the fetal brain and improve symptoms of rats with Parkinson's disease. Proc Natl Acad Sci USA 2008; 105(15): 5856-5861.

66. Takahashi K, Tanabe K, Ohnuki M, et al. Induction of pluripotent stem cells from adult human fibroblasts by defined factors. Cell 2007; 131: 861-872.

67. Yu J, Vodyanik MA, Smuga-Otto K, et al. Induced pluripotent stem cell lines derived from human somatic cells. Science 2007; 318(5858): 1917-1920.

68. Park IH, Zhao R, West JA, et al. Reprogramming of human somatic cells to pluripotency with defined factors. Nature 2008; 451(7175): 141-146.

69. Lowry WE, Richter L, Yachechko R, et al. Generation of human induced pluripotent stem cells from dermal fibroblasts. Proc Natl Acad Sci USA 2008; 105(8): 2883-2888.

70. Dimos JT, Rodolfa KT, Niakan KK, et al. Induced Pluripotent Stem Cells Generated from Patients with ALS Can Be Differentiated into Motor Neurons. Science 2008; 321: 1218-1221.

71. Park IH, Arora N, Huo H, et al. Disease-specific induced pluripotent stem cells. Cell 2008; 134: 877-886.

72. Wilmut I. Shinya Yamanaka \& James Thomson. Time 2008 May 12; 171(19): 96.

73. Cibelli J. Development. Is therapeutic cloning dead? Science 2007; 318(5858): 1879-1880.

Recibido: 4 de marzo de 2009

Aceptado: 16 de mayo de 2009 